\title{
A Critical Review of Factors Affecting Manpower and Equipment Productivity in Tall Building Construction Projects
}

\author{
*Mudumbai Krishnaswamy Parthasarathy', Rajiah Murugasan' and \\ Kavitha Murugesan²
}

Published online: 24 November 2017

\begin{abstract}
To cite this article: Mudumbai Krishnaswamy Parthasarathy, Rajiah Murugasan and Kavitha Murugesan. (2017). A critical review of factors affecting manpower and equipment productivity in tall building construction projects. Journal of Construction in Developing Countries, 22(Supp. 1): 1-18. https://doi.org/10.21315/jcdc2017.22.suppl.1
\end{abstract}

To link to this article: https://doi.org/10.21315/jcdc2017.22.suppl.1

\begin{abstract}
Developing countries have seen an increase in construction of tall buildings in metropolitan cities due to space constraint. The construction of tall buildings in developing countries is undertaken as a combination of manpower and equipment to economize costs. This combination or interface of manpower and equipment, particularly in the basic activities such as concreting, reinforcement, formwork, blockwork, and plastering affects productivity of both the resources. This research aims at studying the factors affecting productivity of manpower and equipment at the micro level for the basic activities of construction for tall building projects. The factors have been further grouped and combined as sections. Responses collected through questionnaire survey from 109 personnel associated with the construction of 72 tall buildings in different geographies of India have been analysed using theoretical tools like frequency index, Spearman's rank correlation coefficient, and factor analysis. The factors have been prioritized in descending order of frequency indices. Based on analysis, it is found that factors in human and planning groups are more influential and affect manpower and equipment productivity significantly. Contract managers and cost engineers can use this study to make allowance while analysing productivity and estimating costs for tall buildings having combined usage of manpower and equipment.
\end{abstract}

Keywords: Productivity, Developing countries, Tall buildings, Manpower, Equipment

\section{INTRODUCTION}

The construction industry is one of the largest contributors to gross domestic product in developing countries and usually second after agriculture. Among many construction sectors, building construction is the most important sector gaining momentum in recent years. Due to space constraint in urban localities, the construction of tall buildings has become inevitable.

Construction of tall buildings involves three types of major resources for execution - manpower, materials, and equipment. The construction of tall buildings in developing countries involves considerable usage of both manpower and equipment. Complete mechanization is not practised due to availability of abundant manpower at lesser cost. The productivity of manpower and equipment in terms of quantity of work done in different activities of construction has lot of variations due to several factors. Most of these factors affecting the productivity of manpower and equipment are correlated and can be grouped distinctly.

\footnotetext{
'Department of Civil Engineering, Anna University, Chennai, INDIA 2Larsen and Toubro Limited, Construction Division, Chennai, INDIA "Corresponding author: balaji_parth@hotmail.com
} 
Many studies have tried to analyse the factors affecting productivity of manpower and equipment. Most of them have been project specific or area specific (Santosh, 2014). However, in tall buildings, studies regarding factors affecting productivity of manpower and equipment for basic activities of construction (concreting, reinforcement, formwork, blockwork, and plastering) are a new area of research. In addition, how these factors affect productivity in case the construction is carried out with a combination of manpower and equipment is also included in this study.

This study aims at understanding the factors affecting productivity of manpower and equipment in tall building construction projects by way of responses received from execution personnel in 72 tall building projects, understanding the frequency and correlation between these factors by which productivity gets affected. Buildings more than $30 \mathrm{~m}$ in height are considered as tall buildings in this study.

\section{STUDY AREA}

The study area of this research is focused on projects in India considering the following reasons:

1. India is one of the developing countries where tall building construction projects are going through significant progress.

2. Many tall building projects are under construction in different regions of the country.

3. Construction in India is done as a combination of manpower and equipment. Manpower is used extensively in construction due to economic and employment factors in construction in addition to operators of equipment.

4. The availability and ease of collecting data.

Though the study has been done in tall building projects across India, the outcome of the research can be applied to all tall building construction projects in any country involving a combination of manpower and equipment with significant involvement of manpower resources.

\section{LITERATURE REVIEW}

Several studies have been carried out globally in the areas of labour productivity, equipment productivity, and tall buildings in construction. The objectives of these studies have been to determine the factors affecting productivity of manpower and equipment in construction in the relevant area of study. A few of them are critically reviewed.

Dai et al. (2009) has carried out research based on industry projects across the U.S. to arrive at their result. They had identified 83 factors as factors affecting labour productivity, from which they had arrived at 10 latent factors that affect labour productivity in a major way.

In India, a study was conducted by Mistry and Bhatt (2013) to find critical factors affecting labour productivity. This study included a survey in cities of South Gujarat, on civil contractors. Based on analysis of their feedback using Analytic 
Hierarchy Process (AHP) and Relative Importance Index (RII) techniques, five crucial factors were identified.

El-Gohary and Aziz (2014) have conducted a specific study on the Egyptian construction industry in which the factors have been identified, investigated, and ranked based on their effect on construction labour productivity with respect to their relative importance. There is a brief mention about working in heights in this study, but it has not been further analysed.

Nguyen and Nguyen (2013) have done a case study to determine the relationship between floor number and labour productivity in multi-storey structural work. However, this study focused only on formwork and reinforcement activities. Furthermore, this study was done based on structural works in one apartment building and hence cannot be considered as a theory in general for all tall buildings.

There is not much study on productivity and factors specifically in tall building projects. Table 1 summarises a few of the studies done in the recent past and the identified major factors affecting productivity.

Table 1. Summary of Literature

\begin{tabular}{|c|c|c|c|c|c|c|}
\hline S. No. & Author(s) & Year & $\begin{array}{l}\text { Study } \\
\text { Method }\end{array}$ & $\begin{array}{l}\text { Area of } \\
\text { Study }\end{array}$ & $\begin{array}{l}\text { Number } \\
\text { of Factors } \\
\text { Considered }\end{array}$ & $\begin{array}{l}\text { Major Factors Affecting } \\
\text { Productivity }\end{array}$ \\
\hline 1 & Dai et al. & 2009 & $\begin{array}{l}\text { Questionnaire } \\
\text { survey and } \\
\text { regression } \\
\text { analysis }\end{array}$ & USA & 83 & $\begin{array}{l}\text { Construction equipment, } \\
\text { materials, tools and } \\
\text { consumables, engineering } \\
\text { drawing management, } \\
\text { direction and coordination, } \\
\text { project management, training, } \\
\text { craft worker qualification, } \\
\text { superintendent competency, } \\
\text { and foreman competency. }\end{array}$ \\
\hline 2 & $\begin{array}{l}\text { Enshassi } \\
\text { et al. }\end{array}$ & 2010 & $\begin{array}{l}\text { Questionnaire } \\
\text { survey }\end{array}$ & Gaza Strip & 45 & $\begin{array}{l}\text { Material shortage, lack of labour } \\
\text { experience, lack of labour } \\
\text { surveillance, misunderstandings } \\
\text { between labour and } \\
\text { superintendent, and drawings } \\
\text { and specification alteration } \\
\text { during execution. }\end{array}$ \\
\hline 3 & $\begin{array}{l}\text { Mistry and } \\
\text { Bhatt }\end{array}$ & 2013 & $\begin{array}{l}\text { Questionnaire } \\
\text { survey }\end{array}$ & India & 27 & $\begin{array}{l}\text { Delay in payments, skill of labour, } \\
\text { clarity of technical specification, } \\
\text { shortage of materials, and } \\
\text { motivation of labour. }\end{array}$ \\
\hline 4 & $\begin{array}{l}\text { Chigara and } \\
\text { Moyo }\end{array}$ & 2014 & $\begin{array}{l}\text { Questionnaire } \\
\text { survey }\end{array}$ & Zimbabwe & 40 & $\begin{array}{l}\text { Unavailability of materials, late } \\
\text { payment of salaries and wages, } \\
\text { suitability/adequacy of plant } \\
\text { and equipment, supervisory } \\
\text { incompetence, and lack of } \\
\text { manpower skills. }\end{array}$ \\
\hline 5 & Robles et al. & 2014 & $\begin{array}{l}\text { Questionnaire } \\
\text { survey }\end{array}$ & Spain & 35 & $\begin{array}{l}\text { Shortage or late supply of } \\
\text { materials, clarity of the drawings } \\
\text { and project documents, clear } \\
\text { and daily task assignment, tools } \\
\text { or equipment shortages, level of } \\
\text { skill, and experience of labourers. }\end{array}$ \\
\hline
\end{tabular}


Table 1. (continued)

\begin{tabular}{|c|c|c|c|c|c|c|}
\hline S. No. & Author(s) & Year & $\begin{array}{l}\text { Study } \\
\text { Method }\end{array}$ & $\begin{array}{l}\text { Area of } \\
\text { Study }\end{array}$ & $\begin{array}{l}\text { Number } \\
\text { of Factors } \\
\text { Considered }\end{array}$ & $\begin{array}{l}\text { Major Factors Affecting } \\
\text { Productivity }\end{array}$ \\
\hline 6 & $\begin{array}{l}\text { Shashank } \\
\text { et al. }\end{array}$ & 2014 & $\begin{array}{l}\text { Question-naire } \\
\text { survey and } \\
\text { regression } \\
\text { analysis }\end{array}$ & India & 34 & $\begin{array}{l}\text { Manpower group, managerial } \\
\text { group, motivation group, } \\
\text { material/equipment group, } \\
\text { safety group, and quality group. }\end{array}$ \\
\hline 7 & $\begin{array}{l}\text { Gupta and } \\
\text { Kansal }\end{array}$ & 2014 & $\begin{array}{l}\text { Question-naire } \\
\text { survey }\end{array}$ & India & 45 & $\begin{array}{l}\text { Clarification in technical } \\
\text { specifications, labour } \\
\text { supervisions, method of } \\
\text { construction, delay in payment, } \\
\text { labour fatigue, lack of leadership } \\
\text { in construction managers, } \\
\text { extents of variations/change } \\
\text { order during executions, late } \\
\text { arrival, early quit, and frequent } \\
\text { unscheduled breaks, labour skill, } \\
\text { and availability of experienced } \\
\text { labour. }\end{array}$ \\
\hline 8 & $\begin{array}{l}\text { Nguyen and } \\
\text { Nguyen }\end{array}$ & 2013 & Case study & Vietnam & - & $\begin{array}{l}\text { Labour productivity of the } \\
\text { formwork activity increased } \\
\text { more than twice in the first five } \\
\text { floors. } \\
\text { Labour productivity of the rebar } \\
\text { activity tended to increase in the } \\
\text { first } 15 \text { floors. } \\
\text { Study indicated variance in } \\
\text { productivity levels for these } 2 \\
\text { activities. }\end{array}$ \\
\hline
\end{tabular}

To summarize the literature referred, studies have been done for construction industry as a whole whereas a few are done specific for building construction projects. Though there is a brief mention about working in heights in some of the studies, detailed research was not carried out in that area. In one of the researches, a case study was done on labour productivity (Attar, Gupta and Desai, 2014) for a tall apartment building, but with limited scope (Gundecha, 2012). There is not much study on productivity specifically in tall building projects and hence this research is proposed in the area of tall buildings.

The important factors affecting productivity highlighted in these studies are skill of labour, experience of labour, availability of materials, and labour supervision (Abdul Karim et al., 2013). The factors affecting manpower productivity is the only focus in many studies. In few cases, equipment productivity is taken as a separate research (Patil, 2015). Hence, this study focuses on factors affecting manpower and equipment productivity where both are used in combination in tall building projects, particularly in developing countries.

In literature, the factors affecting productivity have been listed out by brainstorming among stakeholders or seeking expert opinions or by referring previous studies. After the factors are identified, usually a structured questionnaire survey is conducted, results of the survey are analysed, and conclusions are drawn. In this research, a similar methodology has been undertaken for the study area of tall building projects to identify and analyse factors affecting manpower productivity and equipment productivity. 


\section{OBJECTIVES OF THE STUDY}

1. To list out the factors affecting productivity of manpower and equipment in tall building projects.

2. To make groups of listed factors based on similarities as to how they affect productivity, separately for manpower and equipment.

3. To find out the frequency index of various factors and determine the order of importance of various factors.

4. To find the correlation between the factors using Spearman's rank correlation coefficient and find the intensity of correlation among factors.

5. To further organise the groups into sections separately for manpower and equipment based on correlation.

6. To provide conclusions based on the theoretical methods above, on the importance of these factors, and how they affect productivity of manpower and equipment in tall building projects.

\section{RESEARCH METHODOLOGY}

The research work involves the following steps:

1. Identification of tall building projects executed in India.

2. Design of questionnaire listing out the factors affecting productivity of manpower and equipment under particular sub heads. The important factors and groups were selected as per the opinion given by the respondents based on their experience and empirical data.

3. Distributing the questionnaire to the personnel involved in the execution of the selected 72 tall building projects. Questionnaires were distributed and responses were taken from 109 personnel involved in these projects.

4. Analysis of the responses received using tools like frequency index, Spearman's correlation coefficient, and factor analysis by centroid method.

5. Data interpretation and validation.

6. Conclusions and recommendations.

\section{DATABASE DEVELOPMENT}

The research was planned to be conducted in ongoing tall building projects in India. The following terminologies are used in this study for further discussion:

1. Factors: those that independently affect productivity;

2. Groups: set of similar factors; and

3. Sections: two or more groups together. 


\section{Project Selection Criteria}

Project selection was based on the following criteria:

1. The final height of the building to be more than $30 \mathrm{~m}$.

2. The building has framed reinforced cement concrete structure with a column slab module without any composite construction.

3. The project has all the five basic activities at different heights.

4. The height of each floor to floor was $3 \mathrm{~m}$ to $4 \mathrm{~m}$ only (normal floor height in India).

5. The projects with more or less equal distribution geographically across the country.

Considering the above criteria, 72 tall building construction projects have been chosen for the study. The geographic distribution of the selected projects across India is shown in Figure 1.

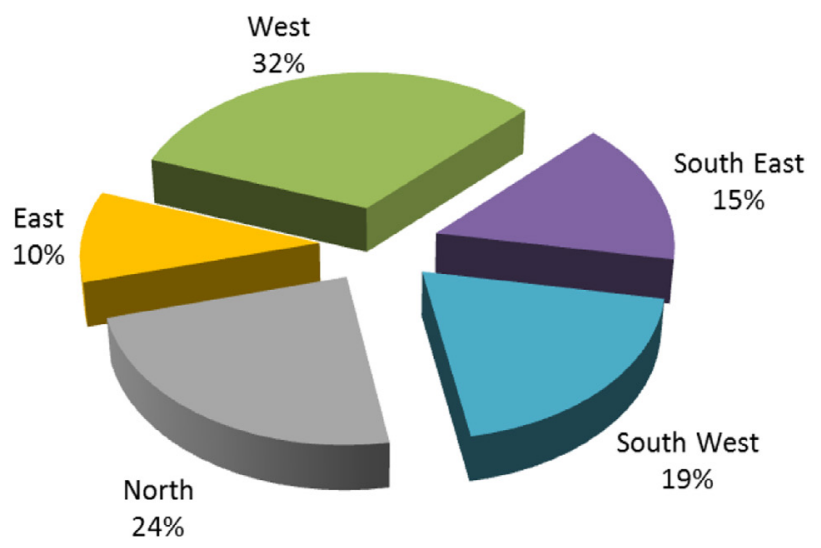

Figure 1. Geographic Distribution of Projects across India

\section{Factors Selection}

Among many factors identified from literature study, a set of 21 factors affecting the productivity of manpower and 20 factors affecting the productivity of equipment were shortlisted to suit Indian conditions and these factors were grouped considering the similarities based on the following:

1. The opinion of the personnel involved in the construction of tall building projects based on their experience.

2. Empirical data on losses due to productivity from a multinational organisation in the area of study.

3. The opinions of contract managers while costing for tall building projects.

The list of factors considered for this study and their classification in respective groups are shown in Table 2. 
Table 2. Factors Affecting Manpower and Equipment Productivity

\begin{tabular}{|c|c|c|c|c|}
\hline \multirow[b]{2}{*}{ Group } & \multicolumn{2}{|r|}{ Equipment Productivity } & \multicolumn{2}{|r|}{ Manpower Productivity } \\
\hline & $\begin{array}{l}\text { Factor } \\
\text { No. }\end{array}$ & $\begin{array}{l}\text { Factors Affecting } \\
\text { Equipment Productivity }\end{array}$ & $\begin{array}{l}\text { Factor } \\
\text { No. }\end{array}$ & $\begin{array}{c}\text { Factors Affecting Manpower } \\
\text { Productivity }\end{array}$ \\
\hline \multirow[t]{3}{*}{ Human factors } & 1 & Lack of skill of operator & $\begin{array}{l}1 \\
2\end{array}$ & $\begin{array}{l}\text { Lack of skill } \\
\text { Lack of motivation }\end{array}$ \\
\hline & 2 & Lack of support staff & $\begin{array}{l}3 \\
4\end{array}$ & $\begin{array}{l}\text { Improper team formation } \\
\text { Lack of supervision }\end{array}$ \\
\hline & 3 & $\begin{array}{l}\text { Lack of proper } \\
\text { maintenance }\end{array}$ & $\begin{array}{l}5 \\
6\end{array}$ & $\begin{array}{l}\text { Threatening by } \\
\text { management } \\
\text { Senior pressure/competition }\end{array}$ \\
\hline \multirow[t]{3}{*}{$\begin{array}{l}\text { Planning } \\
\text { factors }\end{array}$} & 1 & Improper planning of work & 1 & $\begin{array}{l}\text { Improper planning of main } \\
\text { works }\end{array}$ \\
\hline & 2 & Non-availability of materials & 2 & $\begin{array}{l}\text { Improper planning of } \\
\text { support works }\end{array}$ \\
\hline & 3 & Interfacing of activities & $\begin{array}{l}3 \\
4\end{array}$ & $\begin{array}{l}\text { Non-availability of tools } \\
\text { Non-availability of materials }\end{array}$ \\
\hline \multirow[t]{3}{*}{ System factors } & 1 & $\begin{array}{l}\text { Improper access and } \\
\text { egress }\end{array}$ & $\begin{array}{l}1 \\
2\end{array}$ & $\begin{array}{l}\text { Improper access and egress } \\
\text { Long lead }\end{array}$ \\
\hline & 2 & Excess travel/lifting & $\begin{array}{l}3 \\
4\end{array}$ & $\begin{array}{l}\text { Excess lift } \\
\text { Lack of standard procedures }\end{array}$ \\
\hline & 3 & Non-payment of dues & $\begin{array}{l}5 \\
6 \\
7\end{array}$ & $\begin{array}{l}\text { Non-payment of dues/salary } \\
\text { Improper house keeping } \\
\text { Not using advanced systems }\end{array}$ \\
\hline \multirow[t]{2}{*}{$\begin{array}{l}\text { Environmental } \\
\text { factors }\end{array}$} & 1 & Extreme weather conditions & $\begin{array}{l}1 \\
2\end{array}$ & $\begin{array}{l}\text { Extreme climatic conditions } \\
\text { Lack of proper illumination }\end{array}$ \\
\hline & 2 & Lack of water/ hygiene & $\begin{array}{l}3 \\
4\end{array}$ & $\begin{array}{l}\text { Accommodation, transport } \\
\text { Lack of water/sanitation }\end{array}$ \\
\hline \multirow{9}{*}{$\begin{array}{l}\text { Resource/ } \\
\text { equipment } \\
\text { factors }\end{array}$} & 1 & Lack of support equipment & - & - \\
\hline & 2 & Non-availability of fuel & & \\
\hline & 3 & Spares not available & & \\
\hline & 4 & Lead time & & \\
\hline & 5 & $\begin{array}{l}\text { Delay in installing the } \\
\text { equipment }\end{array}$ & & \\
\hline & 6 & $\begin{array}{l}\text { Two or more gangs sharing } \\
\text { an equipment }\end{array}$ & & \\
\hline & 7 & Equipment breakdown & & \\
\hline & 8 & Substandard spares etc. & & \\
\hline & 9 & $\begin{array}{l}\text { Use of high end equipment } \\
\text { where not required }\end{array}$ & & \\
\hline
\end{tabular}




\section{Data Collection}

Once the projects and factors were identified, a questionnaire was prepared and distributed to a set of 109 people across the construction industry, with varied experience in building construction, especially in the area of tall building construction. The people selected to answer this survey were from civil engineering background, all of them were working in or were associated with tall building construction projects. To get the views of people outside the project construction area, questionnaires were distributed and opinions were taken from some designers and sub-contractors involved in the tall building projects. However, it was ensured that all the people who participated in this survey were part of the team working in the listed 72 tall building projects. The respondents were requested in the questionnaire to give their response only on the intensity of the particular factor affecting productivity (i.e., "affects strongly", "affects significantly", "affects moderately", "does not affect" and "cannot say"). The questionnaire was prepared using Microsoft Office software and responses were collected in person or through e-mails.

\section{DATA ANALYSIS}

\section{Details of Responses}

The questionnaire responses collected from 109 personnel who were involved in the execution of the 72 selected tall building projects were tabulated using Microsoft Excel to know the priority of their responses to the various factors. The responses to the factors affecting manpower and equipment productivity have been separately analysed. The summary of responses for factors affecting manpower productivity is given in Table 3.

Table 3. Summary of Responses: Manpower Productivity

\begin{tabular}{clccccc}
\hline S. No. & \multicolumn{1}{c}{ Factors } & $\begin{array}{c}\text { Affects } \\
\text { Strongly }\end{array}$ & $\begin{array}{c}\text { Affects } \\
\text { Significantly }\end{array}$ & $\begin{array}{c}\text { Affects } \\
\text { Moderately }\end{array}$ & $\begin{array}{c}\text { Does Not } \\
\text { Affect }\end{array}$ & $\begin{array}{c}\text { Cannot } \\
\text { Say }\end{array}$ \\
\hline 1 & Human factors & 39 & 37 & 27 & 4 & 2 \\
2 & Planning factors & 59 & 35 & 14 & 1 & 0 \\
3 & System factors & 27 & 42 & 31 & 7 & 3 \\
4 & Environmental factors & 23 & 44 & 33 & 6 & 2 \\
\hline
\end{tabular}

The summary of responses for factors affecting equipment productivity is given in Table 4. 
Table 4. Summary of Responses: Equipment Productivity

\begin{tabular}{clccccc}
\hline S. No. & \multicolumn{1}{c}{ Factors } & $\begin{array}{c}\text { Affects } \\
\text { Strongly }\end{array}$ & $\begin{array}{c}\text { Affects } \\
\text { Significantly }\end{array}$ & $\begin{array}{c}\text { Affects } \\
\text { Moderately }\end{array}$ & $\begin{array}{c}\text { Does Not } \\
\text { Affect }\end{array}$ & $\begin{array}{c}\text { Cannot } \\
\text { Say }\end{array}$ \\
\hline 1 & Human factors & 35 & 48 & 24 & 3 & 0 \\
2 & Planning factors & 54 & 37 & 14 & 2 & 1 \\
3 & System factors & 26 & 46 & 27 & 7 & 2 \\
4 & Resource/equipment factors & 30 & 43 & 26 & 7 & 2 \\
5 & Environmental factors & 19 & 41 & 39 & 9 & 3 \\
\hline
\end{tabular}

\section{Frequency Indices}

The frequency index of each of the various factors was obtained using the standard formula and substituting the responses from the 109 personnel using SPSS software and Microsoft Excel software. The frequency indices for factors affecting manpower productivity are shown in descending order in Figure 2. The frequency indices for factors affecting equipment productivity are shown in descending order in Figure 3.

\section{Inference}

By observing the frequency index of each of the factors affecting manpower and equipment productivity, it can be concluded that the selected factors are all important factors affecting productivity as the frequency index of more than $90 \%$ of the factors are greater than 0.7. It can be inferred that these are the factors which affect manpower and equipment productivity in tall building projects more significantly.

\section{Factor Analysis}

After calculating the frequency indices for all the factors, the groups of factors given in Table 2 were taken for further analysis along with the frequency indices of individual factors. Factor analysis using centroid method was conducted as detailed below.

The correlation of these different groups was established using Spearman's correlation coefficient $(r)$ as per the formula given below:

$$
r=1-\frac{6 \Sigma d^{2}}{n\left(n^{2}-1\right)}
$$

where,

$d$ is the difference between frequency indices

$n$ is the number of observations. 


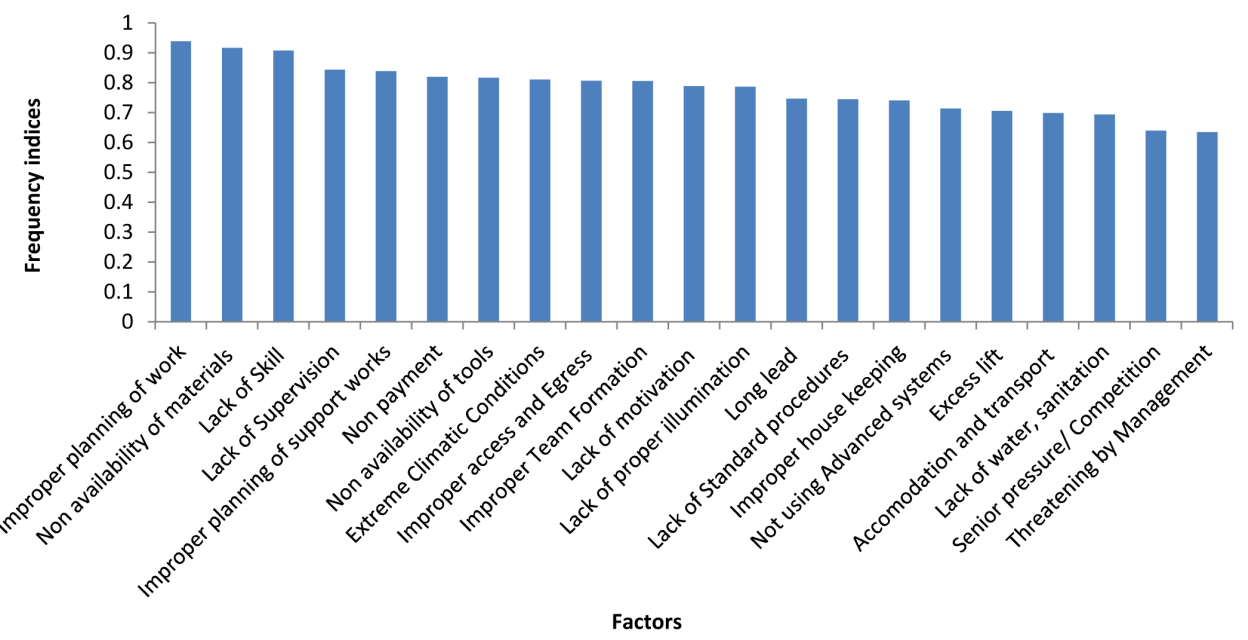

Figure 2. Frequency Index: Factors Affecting Manpower Productivity
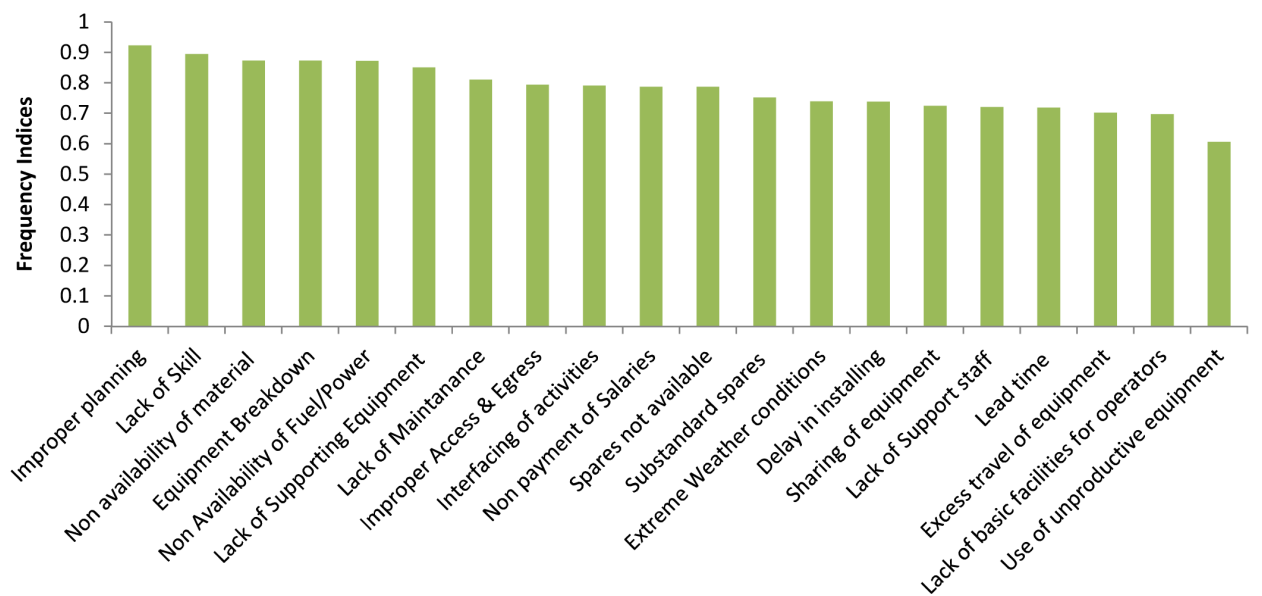

Factors

Figure 3. Frequency Index: Factors Affecting Equipment Productivity

The matrix of the correlation coefficients calculated by the Spearman's correlation coefficient formula for manpower productivity is given in Table 5. 
Table 5. Correlation Coefficient Matrix of Factors Affecting Manpower Productivity

\begin{tabular}{lcccc}
\hline \multicolumn{1}{c}{ Factors } & Human & Planning & System & Environmental \\
\hline Human & 1.000 & 0.996 & 0.998 & 0.999 \\
Planning & 0.996 & 1.000 & 0.998 & 0.992 \\
System & 0.998 & 0.998 & 1.000 & 1.000 \\
Environmental & 0.999 & 0.992 & 1.000 & 1.000 \\
\hline
\end{tabular}

The matrix of the correlation coefficients calculated by the Spearman's correlation coefficient formula for equipment productivity is given in Table 6 .

Table 6. Correlation Coefficient Matrix of Factors Affecting Equipment Productivity

\begin{tabular}{lccccc}
\hline \multicolumn{1}{c}{ Factors } & Human & Planning & System & Resource & Environmental \\
\hline Human & 1.000 & 0.994 & 0.997 & 0.999 & 0.992 \\
Planning & 0.994 & 1.000 & 0.989 & 0.999 & 0.983 \\
System & 0.997 & 0.989 & 1.000 & 0.999 & 0.999 \\
Resource & 0.999 & 0.999 & 0.999 & 1.000 & 0.999 \\
Environmental & 0.992 & 0.983 & 0.999 & 0.999 & 1.000 \\
\hline
\end{tabular}

The factors affecting manpower and equipment productivity, which were classified into groups were further formed to two sections of groups for manpower productivity and three sections of groups for equipment productivity.

The formation of sections from groups was done considering the correlation of the different factors, using experience of the respondents and considering how they affect productivity. The formation of sections from groups for manpower productivity is given below:

\section{Sections - manpower}

1. Section 1: Human, Planning

2. Section 2: Environmental, System below:

The formation of sections from groups for equipment productivity is given

\section{Sections - equipment}

1. Section 1: Human, Planning

2. Section 2: System, Resource

3. Section 3: Environmental 
The variances calculated from the factor analysis have been plotted in the form of bar charts. Microsoft Excel was used for calculating the variances and for plotting the charts. The summary of the variance for manpower productivity and equipment productivity is shown in Figures 4 and 5, respectively.

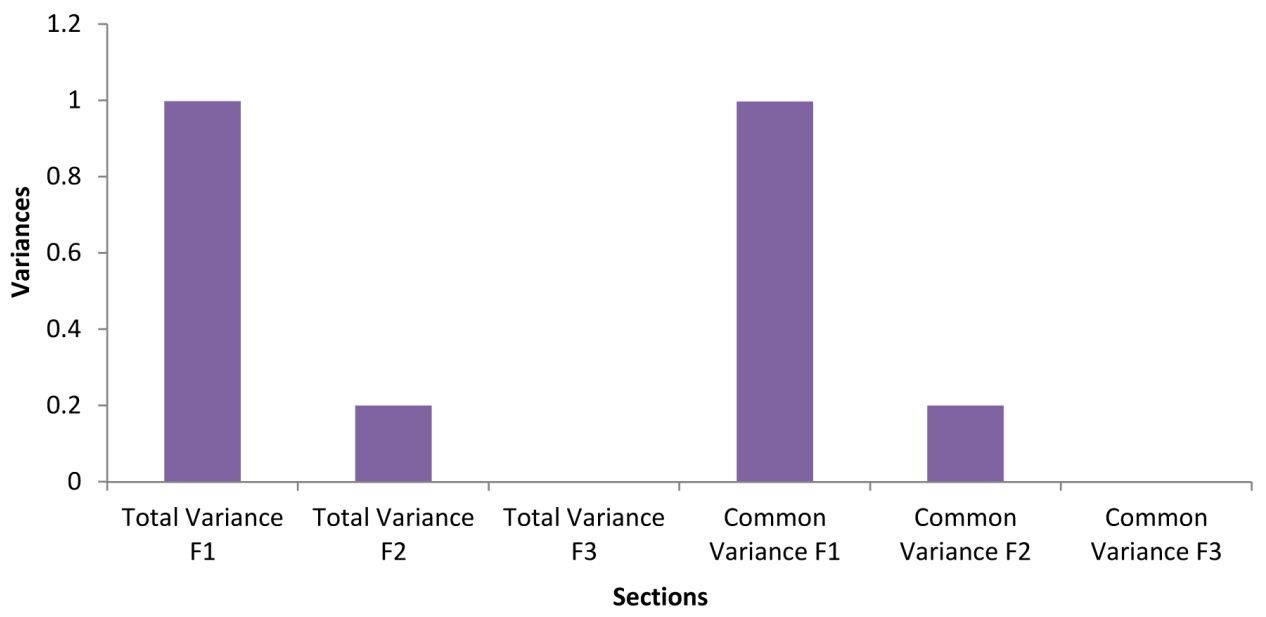

Figure 4. Manpower Productivity Variances

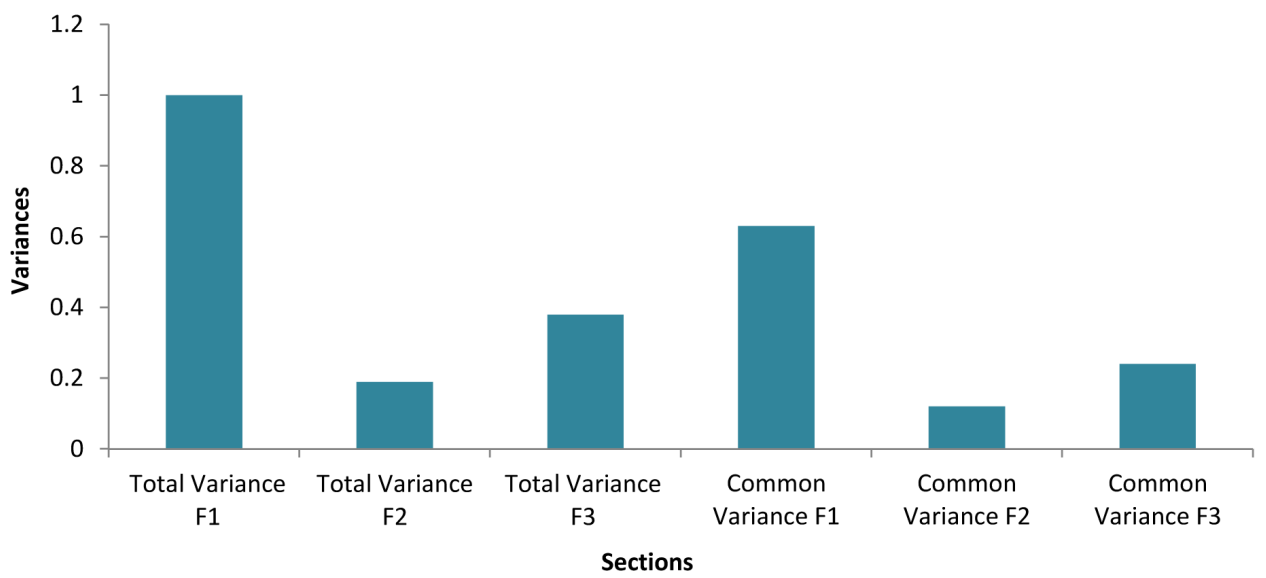

Figure 5. Equipment Productivity Variances

The factor analysis also confirms the fact that there is a correlation among the groups and sections. Factor analysis also confirms that the factors affecting manpower and equipment have to be analysed separately. The groups Human factors and Planning factors have a strong correlation and affect productivity significantly. 


\section{Statistical Validity}

\section{Eigenvalue check for similarity}

The Eigenvalues derived using Microsoft Excel in the factor analysis are given in Table 7.

Table 7. Eigenvalue Statistic

\begin{tabular}{lcll}
\hline \multicolumn{1}{c}{ Manpower Productivity } & \multicolumn{3}{c}{ Equipment Productivity } \\
\hline Factor 1: Human, Planning & 3.991 & Factor 1: Human, Planning & 4.98 \\
Factor 2: System, Environment & 0.008 & Factor 2: System, Resource & 0.95 \\
- & - & Factor 3: Environment & 1.92 \\
\hline
\end{tabular}

If the Eigenvalue of a factor is more than or equal to 1 , then the factor is to be retained. Considering this criterion, Factor 1 in manpower productivity and Factors 1 and 3 in equipment productivity are to be retained. However, considering that Factor 2 in equipment productivity has a correction of $5 \%$ only, the same has also been retained.

\section{Kaiser-Meyer-Olkin (KMO) check for adequacy of data}

The Measures of Sampling Adequacy (MSA) in KMO statistic was calculated using "R" software for the correlation matrix and the values for each variable as well as overall is given in Table 8.

Table 8. KMO Statistic

\begin{tabular}{llll}
\hline Manpower Productivity & & Equipment Productivity \\
\hline Human factors & 0.68 & Human factors & 0.50 \\
Planning factors & 0.65 & Planning factors & 0.54 \\
System factors & 0.82 & System factors & 0.46 \\
Environmental factors & 0.65 & Resource factors & 0.36 \\
& & Environmental factors & 0.41 \\
$\begin{array}{l}\text { Overall score for manpower } \\
\text { productivity }\end{array}$ & 0.69 & $\begin{array}{l}\text { Overall score for equipment } \\
\text { productivity }\end{array}$ & 0.44 \\
\hline
\end{tabular}

For variable with $\mathrm{KMO}$ values greater than 0.50 , it can be considered that component or factor analysis will be useful for these variables. Variables having $\mathrm{KMO}$ values less than 0.50 require remedial action.

In this case, the KMO values for human factors and planning factors are greater than 0.50. It implies that factor analysis is useful for these factors. For factors with $\mathrm{KMO}$ less than 0.50 , the variables also reflect responses to the questionnaire the high or low scores may reflect the trait. The low KMO value may also be due to negatively worded items in the questionnaire and their responses thereof. 


\section{Inferences}

Based on the data analysis, it is inferred that all the factors considered have a significant influence on the productivity of manpower and equipment. However, there is no correlation between the factors affecting manpower productivity and the factors affecting equipment productivity. Further, it has been observed that the groups formed under Section 1 (Human and Planning) in each category manpower and equipment - are the most correlated with the productivity and hence have the most influence on the same.

\section{PROOF OF CONCEPT}

The analysis and results of the research were again taken back to the experts for their opinion in form of a questionnaire. The opinions were taken from 22 experts who had responded to the previous questionnaire. The experts were requested to give their opinion on the top five factors affecting productivity of manpower and equipment independently without reference to their old responses and provide their current order of preference. The results of the proof of concept analysed using Microsoft Office software are given in Table 9 for manpower productivity and Table 10 for equipment productivity.

From Tables 9 and 10 we can observe that the higher numbers are aligned in diagonals, which infers that the experts' opinions are in line with the results of the study with regard to the top five factors affecting productivity of manpower and equipment. The experts have also given their opinion mostly as "strongly agree" and "agree" for the top factors affecting productivity, which is in line with the outcome of this research.

Table 9. Proof of Concept: Manpower Productivity

\begin{tabular}{|c|c|c|c|c|c|c|c|c|c|}
\hline \multirow{2}{*}{$\begin{array}{l}\text { Order as Per } \\
\text { Study and } \\
\text { Analysis }\end{array}$} & \multirow{2}{*}{ Factor } & \multicolumn{5}{|c|}{$\begin{array}{l}\text { Revised Preference of } \\
\text { Order (No. of Responses) }\end{array}$} & \multicolumn{3}{|c|}{$\begin{array}{c}\text { Opinion } \\
\text { (No. of Responses) }\end{array}$} \\
\hline & & 1 & 2 & 3 & 4 & 5 & $\begin{array}{l}\text { Strongly } \\
\text { Agree }\end{array}$ & Agree & Disagree \\
\hline 1 & $\begin{array}{l}\text { Improper planning } \\
\text { of work }\end{array}$ & 17 & 2 & 1 & 2 & & 19 & 3 & \\
\hline 2 & $\begin{array}{l}\text { Non-availability of } \\
\text { materials }\end{array}$ & & 9 & 4 & 3 & 6 & 10 & 10 & 2 \\
\hline 3 & $\begin{array}{l}\text { Lack of skill of } \\
\text { workman }\end{array}$ & 3 & 3 & 12 & 3 & 1 & 14 & 7 & 1 \\
\hline 4 & Lack of supervision & 2 & 3 & 2 & 11 & 4 & 10 & 12 & \\
\hline 5 & $\begin{array}{l}\text { Improper planning } \\
\text { of support works }\end{array}$ & 1 & 4 & 2 & 4 & 11 & 9 & 13 & \\
\hline
\end{tabular}


Table 10. Proof of Concept: Equipment Productivity

\begin{tabular}{|c|c|c|c|c|c|c|c|c|c|}
\hline \multirow{2}{*}{$\begin{array}{l}\text { Order as Per } \\
\text { Study and } \\
\text { Analysis }\end{array}$} & \multirow{2}{*}{ Factor } & \multicolumn{5}{|c|}{$\begin{array}{c}\text { Revised Preference of } \\
\text { Order (No. of Responses) } \\
\end{array}$} & \multicolumn{3}{|c|}{$\begin{array}{l}\text { Opinion } \\
\text { (No. of Responses) }\end{array}$} \\
\hline & & 1 & 2 & 3 & 4 & 5 & $\begin{array}{l}\text { Strongly } \\
\text { Agree }\end{array}$ & Agree & Disagree \\
\hline 1 & $\begin{array}{l}\text { Improper planning } \\
\text { of work }\end{array}$ & 18 & & 1 & 1 & 2 & 18 & 3 & 1 \\
\hline 2 & $\begin{array}{l}\text { Lack of skill of } \\
\text { operator }\end{array}$ & 1 & 13 & 3 & 5 & & 14 & 7 & 1 \\
\hline 3 & $\begin{array}{l}\text { Equipment } \\
\text { breakdown }\end{array}$ & 3 & 5 & 13 & 1 & & 16 & 6 & \\
\hline 4 & $\begin{array}{l}\text { Non-availability of } \\
\text { materials }\end{array}$ & & 1 & 3 & 9 & 9 & 7 & 14 & 1 \\
\hline 5 & $\begin{array}{l}\text { Non-availability of } \\
\text { fuel/spares }\end{array}$ & & 2 & 1 & 9 & 10 & 8 & 13 & 1 \\
\hline
\end{tabular}

In addition, the experts were also requested to provide an opinion whether they want to make allowance for productivity in their practice and the opinions by the 22 experts are shown in Table 11.

Table 11. Expert Opinion on Allowances for Productivity Factors

\begin{tabular}{lc}
\hline \multicolumn{1}{c}{ Percentage of Allowance } & Number of Respondents \\
\hline No allowance & 6 \\
Up to 10\% allowance & 7 \\
Allowance greater than 10\% and less than 20\% & 7 \\
Allowance greater than 20\% & 2 \\
\hline
\end{tabular}

From Table 11, it is evident that the experts have felt the need for making allowances for productivity in their practice, being aware of the factors affecting manpower and equipment productivity.

\section{CONCLUSIONS}

Factors affecting manpower and equipment productivity are many in the construction industry. However, to consider and estimate allowances for manpower and equipment productivity, contract managers and cost engineers should understand and identify the most important factors affecting productivity.

1. Based on expert opinion, 21 factors affecting manpower productivity were identified and were segregated into 4 groups - human factors, planning factors, system factors, and environmental factors. Twenty factors affecting equipment productivity were identified and were segregated into five groups - human factors, planning factors, system factors, environmental factors, and resource/ equipment factors (refer Table 2). 
2. The frequency index for the 21 factors affecting manpower productivity and 20 factors affecting equipment productivity were calculated from the responses received through 109 questionnaires. The range of frequency indices for manpower productivity is between 0.635 and 0.939 . The range of frequency indices for equipment productivity is between 0.606 and 0.923 . The factors with higher frequency indices assume higher importance (refer Figures 2 and 3).

3. All these factors are closely correlated as analysed through the Spearman's correlation coefficient. All the factors have an intensity of correlation more than $90 \%$ (values $>0.9$ ). This shows that their effect in the project is in combination and cannot be separated out (refer Tables 5 and 6).

4. The formation of sections using factor analysis for manpower productivity has resulted in two sections. For equipment productivity, this has resulted in three sections. Section 1 consisting of human and planning factors is the most influential on both manpower productivity and equipment productivity.

5. The three important factors affecting manpower productivity are:

(i) Improper planning of work, with frequency index of 0.939.

(ii) Non-availability of materials, with frequency index of 0.917.

(iii) Lack of skill of workman, with frequency index of 0.908.

The three important factors affecting equipment productivity are:

(i) Improper planning of work, with frequency index of 0.923.

(ii) Lack of skill of operator, with frequency index of 0.895.

(iii) Equipment breakdown, with frequency index of 0.873 .

6. All the factors considered in the study affect the productivity of manpower and equipment in tall building projects as the frequency index of 38 out of 41 factors (93\% of the factors) is more than 0.70 (refer Figures 2 and 3).

\section{CONTRIBUTIONS FROM THIS STUDY}

In tall buildings, allowances have to be considered and taken into account in costing for the factors affecting productivity. Commonly, contract managers and cost engineers do not make allowances as they are not able to visualize and prioritize these factors. This research will help them to be aware of the important factors affecting productivity and help them in making allowances towards productivity in costing for tall building projects. This will also help the planning managers of a project to avoid any productivity losses during execution of the project by minimizing the effect of the factors affecting productivity analysed in this study.

\section{LIMITATIONS AND SUGGESTIONS FOR FURTHER STUDY}

The conclusions derived from this study can be used for tall buildings with reinforced cement concrete framed structure of column-beam-slab construction. These factors and study cannot be used for construction of composite structures with structural steel like factories, warehouses, etc. The analysis and findings will be useful 
only when the methodology demands a combination of resource input in the form of manpower and equipment. Substantial amount of manpower is used for the basic activities of construction in developing countries in addition to the equipment operators. The outcome of this study is not applicable for fully mechanized work or fully manpower oriented work.

The effects of monsoon and seasonal variances on productivity are not considered in this study.

Further study can be made for specialized packages such as façade, interior works, etc. for which the equipment and labour requirement will be different from those of the activities covered in this study.

\section{CONFLICT OF INTEREST}

The authors declare that there is no conflict of interests regarding the publication of this paper.

\section{ACKNOWLEDGEMENTS}

The authors would like to take this opportunity to thank all the respondents to the questionnaires, whose immediate and insightful responses have enabled us to complete this research and prepare this article.

\section{REFERENCES}

Abdul Karim, N., Hassan, S., Yunus, J. and Hashim, M. (2013). Factors influence labour productivity and the impacts on construction industry. Caspian Journal of Applied Sciences Research, 2: 349-354.

Attar, A.A., Gupta, A.K. and Desai, D.B. (2014). A study of various factors affecting labour productivity and methods to improve it. IOSR Journal of Mechanical and Civil Engineering, 1 (3): 11-14.

Chigara, B. and Moyo, T. (2014). Factors affecting labor productivity on building projects in Zimbabwe. International Journal of Architecture, Engineering and Construction, 3(1): 57-65. https://doi.org/10.7492/IJAEC.2014.005

Dai, J., Goodrum, P.M., Maloney, W.F. and Srinivasan, C. (2009). Latent structures of the factors affecting construction labor productivity. Journal of Construction Engineering and Management, 135(5): 397-406. https://doi.org/10.1061/ (asce)0733-9364(2009) 135:5(397)

El-Gohary, K.M. and Aziz, R.F. (2014). Factors influencing construction labor productivity in Egypt. Journal of Management in Engineering, 30(1): 1-9. https://doi.org/10.1061/(asce)me.1943-5479.0000168

Enshassi, A., Mohamed, S., Mustafa, Z.A. and Mayer, P.E. (2010). Factors affecting labour productivity in building projects in the Gaza strip. Journal of Civil Engineering and Management, 13(4): 245-254. http://dx.doi.org/10.1080/13 923730.2007.9636444

Gundecha, M.M. (2012). Study of factors affecting labor productivity at a building construction project in USA: Web survey. MSc diss. North Dakota State University. 
Gupta, V. and Kansal, R. (2014). Improvement of construction labor productivity in Chambal region. International Journal of Research in Engineering and Technology, 3(10): 34-37. https://doi.org/10.15623/ijret.2014.0310006

Mistry, S. and Bhatt, R. (2013). Critical factors affecting labour productivity in construction projects. International Journal of Engineering and Advanced Technology, 2(4), 583-591.

Nguyen, L.D. and Nguyen, H.T. (2013). Relationship between building floor and construction labor productivity: A case of structural work. Engineering, Construction and Architectural Management, 20(6): 563-575. https://doi. org/10.1108/ECAM-03-2012-0034

Patil, R. (2015). Estimating construction equipment productivity and economics using stochastic methods. International Journal of Research in Engineering, Science and Technologies, 1 (8): 341-346.

Robles, G., Stifi, A., Ponz-Tienda, J.L. and Gentes, S. (2014). Labor productivity in the construction industry-factors influencing the Spanish construction labor productivity. International Journal of Civil, Environmental, Structural, Construction and Architectural Engineering, 8(10): 1053-1062.

Santosh, V. (2014). Productivity in building construction. IOSR Journal of Mechanical and Civil Engineering, 10(5): 64-71.

Shashank, K., Hazra, S. and Pal, K.N. (2014). Analysis of key factors affecting the variation of labour productivity in construction projects. International Journal of Emerging Technology and Advanced Engineering, 4(5): 152-160. 